\title{
The Importance of Stem Based Education in Indonesia Curriculum
}

\author{
Oktian Fajar Nugroho ${ }^{\text {ab* }}$, Anna Permanasaria ${ }^{\mathrm{a}}$, Harry Firman $^{\mathrm{a}}$, Riandi ${ }^{\mathrm{a}}$ \\ ${ }^{a}$ Faculty of Teacher Training and Education, Universitas Pendidikan Indonesia, Bandung, Indonesia \\ ${ }^{\mathrm{b}}$ Faculty of Teacher Training and Education, Universitas Esa Unggul, Jakarta, Indonesia \\ oktianfajarnugroho@gmail.com*; anna.permanasari@upi,edu; harry.firman@upi.edu; rian@upi.edu \\ *Corresponding author
}

\begin{tabular}{|c|c|}
\hline Article Info & ABSTRACT \\
\hline Article history: & \multirow{9}{*}{$\begin{array}{l}\text { This article describes the importance of the concept of STEM-based } \\
\text { education in the Indonesia curriculum. STEM-based education is an } \\
\text { educational concept that integrates the concept of education into a } \\
\text { single unit between Science, Technology, engineering and } \\
\text { Mathematics, the concept of STEM education has been developed in } \\
\text { various developing and developed countries today. STEM education } \\
\text { does not mean only strengthening educational practice in the fields of } \\
\text { education separately, but rather developing an educational approach } \\
\text { by integrating several subjects such as science, technology, } \\
\text { engineering, and mathematics, by focusing more on the educational } \\
\text { process on solving real problems in everyday life. By developing } \\
\text { various aspects of attitudes, knowledge and skills as well as increasing } \\
\text { critical thinking power and being able to form logical thinking in } \\
\text { various fields of knowledge based on the applicable } 2013 \text { curriculum. }\end{array}$} \\
\hline Received Aug 23, 2021 & \\
\hline Revised Oct 20, 2021 & \\
\hline ed Oct 22, 2021 & \\
\hline Keywords: & \\
\hline Education & \\
\hline STEM Education & \\
\hline Curriculum 2013 & \\
\hline Indonesian Curriculum & \\
\hline
\end{tabular}

This is an open access article under the $\underline{C C B Y-S A}$ license.

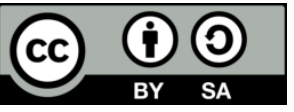

\section{Introduction}

The development of science and technology is increasingly fast, requiring adjustments and acceleration in developing education that is able to take advantage of existing scientific and technological developments. STEM education is part of the latest developments in the field of education to modify learning by integrating various subjects including Science (biology, physics, chemistry), Technology, Engineering and Mathematics. The subjects contained in STEM are subjects whose interest in learning is very low and which is considered difficult by students (Nugroho, 2021). The word STEM was launched by the US National Science Foundation in the 1990s as the theme of the education reform movement in the four disciplines to grow human resources who are ready to work in STEM fields and develop STEM literate citizens, as well as increase US global competitiveness in science and technology innovation (Hanover, 2011). This STEM education reform movement is driven by various research results showing a shortage of ready-to-use personnel in the world of employment in the fields of technology in various developing and developed countries, one of which is our country, Indonesia. Significantly decreased literacy levels in society on 
STEM-related issues, people tend to be more in theoretical fields, and not many practical ones can be used in the world of work. The current attention of the Indonesian government to the field of education is very high by providing additional budgets and building various educational facilities that are already quite adequate. expert support from many universities, as well as technical support from industry, for the development and implementation of STEM education.

STEM education has been widely carried out in various countries including Malaysia and Turkey, both developed and developing countries, which view STEM education as a solution to the problem of the quality of Human Resources and the competitiveness of each country. Therefore, research and development in STEM education has become an interesting and dominant theme in international scientific conferences and publications in the field of education. But in Indonesia not many have done it, but awareness of the importance of STEM education has begun to emerge among education experts in Indonesia, so that many study groups in universities conduct research and development of STEM education. Theses and dissertations within the framework of STEM education have now begun to emerge. STEM education also in its application does not only focus on cognitive development, but also on the level of the affective domain, because STEM education provides space for students to actively participate in learning by working together, disciplined, helping each other in integrating various experiences in their lives, so that STEM education suitable in the formation and development of aspects of knowledge (cognitive), aspects of attitudes (affective) and aspects of skills (psychomotor).

The 2013 curriculum is a curriculum that prioritizes the process in its implementation. The main Graduate Competency Standards (SKL) in the implementation of learning are developing aspects of attitudes, then aspects of skills and knowledge. In this curriculum, students are required to independently seek knowledge in the surrounding environment by utilizing various learning resources and existing learning facilities, students become very active and creative in seeking and building their knowledge. The 2013 curriculum as a complement to the previous curriculum, the 2013 curriculum was designed by integrating character in the implementation process (Dewi, 2018). Therefore, in the 2013 curriculum emerged core competencies (KI) as a reference in the learning process. The concept of STEM education and the 2013 curriculum actually have some similarities in integrating various concepts in learning with the same goal of developing various aspects of attitudes, knowledge and skills.

\section{Method}

Using content analysis methodologies, this study examines the importance of STEM education in Indonesia in the context of 21 st century skills categories. A research technique called content analysis allows researchers to study human behavior indirectly by analyzing products such as textbooks, articles and newspapers as well as songs and political statements as well as images and almost any other form of communication, such as songs and political statements. By examining professional and general publications, content analysis also allows for a better understanding of the direction in which education is changing. It was found that instructors should be taught engineering design abilities as part of STEM education best practices. Using the survey research flow, the research method was carried out. For the article analysis, STEM approach research journals. 


\section{Results and Discussion}

\section{Basic Concepts of STEM}

\section{Definition of STEM Education}

STEM (Science, Technology, Engineering, and Mathematics) education is one of the educational ideas that incorporates various disciplines of science, such as STEM (Science, Technology, Engineering, and Mathematics). Science, one of the STEM components, is the study of natural events that incorporates observation and measurement, as a vehicle for objectively describing nature's ever-changing processes. Physics, biology, chemistry, and earth and space sciences are some of the key science disciplines taught in elementary and secondary schools. Technology refers to human inventions that are used to change nature to satisfy human wants and aspirations, therefore improving and securing the quality of life for all people on the earth. Humans are able to travel fast, interact directly with people in remote locations, obtain nutritious food, and use safety equipment because to technological advancements. To be an engineer, you must have a thorough understanding of economics as well as social sciences in order to develop and build machines that are both economically and ecologically good for people. Moreover, mathematics is the science of patterns and relationships, and it offers the language for technology, science, and engineering to operate.

When we say STEM education, we aren't only talking about enhancing the pedagogy in STEM subjects individually. We're talking about establishing an educational strategy that combines science, technology, engineering, and mathematics (National STEM Education Center, 2014). Students who are STEM literate (Bybee, 2013) are those who:

1) Knowing how to identify questions and problems in everyday circumstances, explain natural occurrences, develop, and make evidence-based judgments regarding STEMrelated topics.

2) STEM disciplines as human-initiated forms of knowledge, investigation, and design;

3) By applying the concepts of science, technology, engineering, and mathematics to challenges linked to STEM (e.g. energy efficiency, environmental quality, limited natural resources), you may become a thoughtful and constructive citizen.

As a result, instructors are able to demonstrate to their pupils how concepts and principles from the STEM disciplines are incorporated into the production of goods, processes and systems that they use on a daily basis. Determining STEM education to be an interdisciplinary approach to learning, Reeve (2013) defines STEM education as a contextbased approach to learning in which students utilize STEM in real-world situations to achieve STEM literacy. pupils to compete in a knowledge-based economy.

\section{The Importance of STEM Education in the 2013 Curriculum}

STEM education is now being adopted by many nations to serve as a model for educational innovation, and it is growing as a worldwide movement to bridge skills gaps needed for economic success in the 21st Century. According to the US Bureau of Labor Statistics, STEM employment will grow by 17 percent in the next decade, whereas nonSTEM employment will only grow by 10 percent (Deming, 2018).

Faced with global competitiveness, Indonesia must also prepare qualified and adequate STEM people resources. Multiple study findings from the Kompas newspaper (July 2015) show that Indonesia has a mismatch between the demand for human resources and the supply of human resources. 88 million unskilled monkeys dominate Indonesia's human resources, according to 2010 statistics from the Central Statistics Agency, and it's anticipated that by 2020 there would be a 50 percent lack of personnel to fill job vacancies. The solution to this 
problem, however, is not straightforward, as it is difficult to expect the next generation to succeed without efforts to develop basic abilities, soft skills (collaboration, communication, creativity, problem solving), and the prerequisite values for entering the STEM professions at the primary and secondary education levels. Motivated young individuals who want to pursue a career in STEM disciplines.

However, if it fails to educate students for 21 st century employment, as shown in STEM Education, then the 2013 curriculum will fail to solve the problem of quality and quantity of Indonesian human resources who are internationally enabled. For the nation's next generation to be able to compete in the global arena, STEM-based education can be the key to overcoming this. For this reason, STEM education must be incorporated into the Indonesian educational system. Abdurakhmanov (2020) explains that Indonesians will be prepared to live as individuals and citizens who are faithful, industrious, creative, inventive, and effective, as well as to contribute to society, country, state, and world civilization.

\section{STEM Education - Based Learning}

One of the characteristics of STEM Education is integrating science, technology, engineering, and mathematics in solving real problems. But it has various ways, including integrating all fields in STEM, but also needing to consider materials, media and other factors (Roberts, 2012). The second way is to teach each STEM discipline by focusing more on one or two of the STEM disciplines. The third way is to integrate one into the three disciplines STEM, for example, engineering content is integrated into science, technology, and mathematics subjects. A more comprehensive way is to fuse all four STEM disciplines and teach them as integrated subjects, such as technology, engineering and math content in science, so that science teachers integrate $\mathrm{T}, \mathrm{E}$, and $\mathrm{M}$ into $\mathrm{S}$.

In the context of general primary and secondary education in many countries, including Indonesia, only science and mathematics are part of the conventional curriculum, while technology and engineering subjects are only a minor part or even absent from the curriculum. Therefore, STEM education is more focused on science and mathematics. In this regard Bybee (2013) conceptualized a continuum of STEM cohesiveness consisting of nine cohesive patterns, ranging from ST-EM disciplines as "silos" (stand-alone subjects) to STEM as transdisciplinary subjects. Deeper integration into the form of transdisciplinary subjects requires a comprehensive curriculum restructuring, making it relatively difficult to implement in the context of the conventional curriculum structure in Indonesia. One possible integration pattern without restructuring the primary and secondary education curriculum in Indonesia is to incorporate engineering, technology, and mathematics content into STEMbased science learning, as illustrated in Figure 1. 


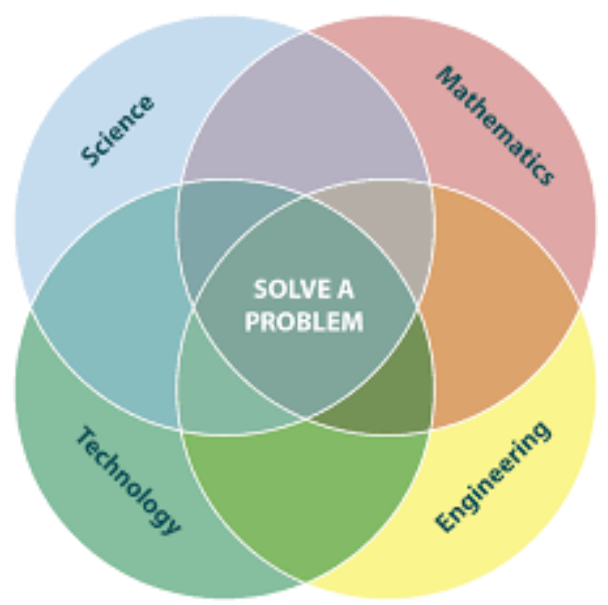

Figure 1. STEM Base Science Learning

The pattern of full integration is relatively easier to do at the elementary school level, when students are taught by a classroom teacher. Meanwhile, the "embedded STEM" form is more appropriate at the high school level. STEM education manifests itself in certain situations when learning science or mathematics involves authentic problem-solving activities in social, cultural, and functional contexts (Roberts, 2012). STEM is a tool to be able to develop mindsets and hone students' critical thinking. Although it is focused on the exact sciences, it does not rule out its social elements (LIPI). Science and mathematics are considered appropriate to be vehicles for bringing STEM Education, because these two subjects are the main subjects in primary and secondary education, and become the basis for students to enter careers in STEM disciplines, which are seen as fundamental to technological innovation and economic productivity (Nugroho, et al 2019)

\section{Conclusion}

Based on the various concepts and discussions above, it can be concluded that the concept of STEM education is very possible to be applied in the 2013 curriculum, by having the same concept of integrating in various concepts in the field of knowledge. Have the same goal in developing aspects of attitudes, knowledge and skills. The concept of STEM Education provides more operational convenience in implementing the 2013 curriculum. The application of STEM-based education will be able to develop critical thinking skills and can form logical thinking in various fields of knowledge, this is in accordance with the objectives to be achieved by the 2013 curriculum. STEM-based education can be applied at various levels. education, especially in primary and secondary schools. Educators and education personnel need to first master the concept of new STEM education that can be ideally applied in the 2013 curriculum.

\section{References}

Abdurakhmanov, K. (2020). Labour Economics: Theory and practice. Scientific Publishing House IVG.

Bybee, R. W. (2010). Advancing STEM education: A 2020 vision. Technology and engineering teacher, $70(1), 30$. 
Bybee, R. W. (2013). The case for STEM education: Challenges and opportunities. NSTA press.

Deming, D. J., \& Noray, K. L. (2018). STEM careers and technological change.

Dewi, W. S., Festiyed, F., Hamdi, H., \& Sari, S. Y. (2018, April). The Study of Literacy Reinforcement of Science Teachers in Implementing 2013 Curriculum. In IOP Conference Series: Materials Science and Engineering (Vol. 335, No. 1, p. 012071). IOP Publishing.

Hanover, R. (2011). Successful K-12 STEM Education. Identifying Effective Approaches in Sciences, Technology, Engineering and Mathematics. Washington. DC. US: National Academies Press. NW. Suite, 300, P202.

National STEM Education Center (2014). STEM education network manual. Bangkok: The Institute for the Promotion of Teaching Science and Technology.

Nugroho, O. F., Permanasari, A., \& Firman, H. (2021). STEM Learning for Science Education Program: Reference to Indonesia. Jurnal Inspirasi Pendidikan, 11(2), 90100.

Nugroho, O. F., Permanasari, A., \& Firman, H. (2019). Program Belajar berbasis STEM untuk Pembelajaran IPA: Tinjauan Pustaka, dengan Referensi di Indonesia. Jurnal Eksakta Pendidikan (JEP), 3(2), 117-125.

Reeve, E. M. (2013). Implementing science, technology, mathematics and engineering (STEM) education in Thailand and in ASEAN. Bangkok: Institute for the Promotion of Teaching Science and Technology (IPST).

Roberts, A. (2012). A justification for STEM education. Technology and engineering teacher, 71(8), 1-4.

Reigeluth, C. M. (1999). What is instructional-design theory and how is it changing. Instructional-design theories and models: A new paradigm of instructional theory, 2, 5-29. 